\title{
Pengelolaan Arsip Dinamis Di Dinas Kearsipan Provinsi Sumatera Selatan
}

\section{Novia Febriyanti, Mia Romiati, Meiliza Trimonita, Nanda Cahyani, Chandra Fauzan Aziaman, Lola Oktafiremi}

\begin{abstract}
The purpose of this study is to find out the management of dynamic records and archival retrieval systems at the Archives Office of South Sumatra Province. This study uses the observation method with data collection techniques in the form of interviews, namely Mr. H. Ir. Muhammad Sidik Faisol, M.Sc as a guest speaker. The results obtained from this study are known that the management of dynamic records in the Office of Archives of South Sumatra Province uses a classification system as a means of structuring the archives so that in the archive storage will be arranged based on classification numbers. The archive destruction method used was enumeration, this method was chosen because it was considered more environmentally friendly than the combustion method. And for the file retrieval system, still by manual or by using a computer system.
\end{abstract}

Keywords: archive management, dynamic archives and archives

\section{Pendahuluan}

Kata pengelolaan bisa disamakan dengan manajemen, yang berarti pengaturan dan pengurusan. Banyak yang mengartikan manajemen merupakan pengaturan, pengelolaan, dan pengadministrasian karena ini adalah pengertian yang paling 
popular. Pengelolaan juga bisa diartikan sebagai rangkaian pekerjaan atau usaha yang dilakukan untuk mencapai tujuan. Secara garis besar tahap-tahap dalam melakukan pengelolaan meliputi perencanaan, pengorganisasian, pelaksanaan dan pengawasan.

Arsip menurut undang-undang No. 7 tahun 1971, arsip adalah: (a) Naskah-naskah yang dibuat dan diterima oleh lembagalembaga dan badan-badan pemerintahan dalam bentuk corak apapun, baik dalam keadaan tunggal maupun berkelompok dalam rangka pelaksanaan kegiatan pemerintahan; (b) Naskah-naskah yang dibuat dan diterima oleh badan-badan swasta atau perorangan, dalam bentuk corak apapun, baik dalam keadaan tunggal maupun berkelompok dalam rangka pelaksanaan kehidupan kebangsaan. (Zulkifli Amsyah, 2003:2)

Arsip merupakan suatu kegiatan yang sangat penting selama suatu organisasi yang masih melaksanakan kegiatannya, baik dalam kegiatan rutin maupun dalam hal pengembangan kegiatan yang dilakukan. Public records arrive at an archival institution during the inactive stage of the records lifecycle (Amber L. Cusing, 2010:302). Hal ini dapat diartikan sebagai catatan dalam arsip dinamis merupakan hal yang penting dalam suatu lembaga baik pemerintah maupun swasta karena merupakan kesinambungan rutinitas dari dari lembaga publik tersebut. Archives as organizational records. In this category, the archive is experienced as a record of the institution and this definition of what constitutes archives and archives affects the focus of this category archive management (Wakimoto, 2015:188). Maksudnya adalah arsip sebagai catatan organisasi. Dalam kategori ini, arsip sebagai 
catatan lembaga dan arsip- arsip ini menjadi fokus dalam pengelolaan arsip.

Dalam pasal 2 UU No. 7 tahun 1971 tentang pokok-pokok kearsipan dijelaskan lebih lanjut bahwa arsip dibedakan menjadi arsip dinamis dan arsip statis. Arsip dinamis adalah arsip yang digunakan secara langsung dalam perencanaan, pelaksanaan, penyelenggaraan kehidupan kebangsaan pada umumnya dan penyelenggaraan administrasi negara. Arsip statis adalah dokumen-dokumen yang bernilai guna dan disimpan di ANRI/arsip daerah.

Salah satu informasi terekam yang dikenal banyak orang adalah dalam bentuk atau istilah kata yang disebut "arsip". Istilah kata ini berhubungan erat dengan kegiatan sehari-hari yang dijalani banyak orang. Kegiatan yang dilakukan akan berhubungan dengan kertas atau media lain, yang mengandung informasi dan mencakup rentang waktu tertentu, baik kegiatan yang baru terjadi maupun kegiatan yang sudah lama terjadi. (Anon Mirmani, 2011:1.11)

Tetapi banyak orang yang tidak memiliki penilaian tentang arti penting dari sebuah arsip, sering kali ditemui berbagai dokumen tertulis yang disimpan secara sembarangan dan di tumpuk. Kesadaran akan pentingnya dokumen tertulis baru akan dirasakan saat diperlukannya dokumen tersebut tetapi sulit untuk temu kembalinya (Anon Mirmani, 2011:1.12). Oleh karena itu, perlu adanya pengelolaan arsip karena salah satu manfaat yang dapat dirasakan dari pengelolaan arsip adalah ketepatan dan kecepatannya dalam temu kembali sebuah informasi.

Pengelolaan arsip juga dilakukan di Kantor Dinas Kearsipan Provinsi Sumatera Selatan. Kantor ini merupakan instansi 
pemerintah yang memang tugasnya untuk mengelola arsip. Arsip yang disimpan tentunya memerlukan pengelolaan yang baik. Arsip yang dikelola dengan baik akan memberikan kemudahan bagi organisasi atau pencipta arsip untuk dapat menemukan arsip dengan cepat ketika dibutuhkan. Namun pengelolaan arsip tidak mudah ada beberapa permasalahan yang timbul sehingga menyebabkan pengelolaan arsip tidak Maksimal. Permasalahan pengelolaan arsip juga dihadapi oleh Dinas Kearsipan Provinsi Sumatera Selatan. Arsip dinamis yang terus bertambah sehingga memerlukan pengelolaan yang baik.

Berdasarkan latar belakang yang telah di paparkan fokus dari tulisan ini adalah mengenai pengelolaan arsip dinamis aktif dan inaktif di Dinas Kearsipan Provinsi Sumatera Selatan.

\section{Rumusan Masalah}

1. Bagaimana Pengelolaan Arsip Dinamis di Dinas Kearsipan Provinsi Sumatera Selatan?

2. Bagaimana Sistem Temu Kembali Arsip di Dinas Kearsipan Provinsi Sumatera Selatan?

\section{Metode Penelitian}

Metode yang digunakan dalam penelitian ini adalah metode observasi, yakni dengan mengamati dan mencari data yang berhubungan dengan permasalahan. Teknik dalam pengumpulan data ini berupa wawancara dengan menyiapkan list wawancara untuk mengajukan beberapa pertanyaan kepada narasumber. Adapun yang menjadi narasumber dalam penelitian ini adalah bapak H. Ir. Muhammad Sidik Faisol, M.Si yakni Arsiparis Ahli Madya.

\section{Pembahasan}


1. Pengertian Arsip Dinamis

Arsip dinamis berasal dari Bahasa Belanda dynamish archief. Arsip dinamis (dokumen atau record) merupakan informasi terekam termasuk data dalam sistem komputer yang dibuat atau diterima oleh badan korporasi atau perorangan dalam transaksi kegiatan atau melakukan tindakan sebagai bukti aktivitas. Arsip dinamis merupakan arsip yang diperlukan dalam perencanaan, pelaksanaan, penyelenggaraan kehidupan kebangsaan pada umumnya dan penyelenggaraan admisitrasi negara pada khusunya.

Arsip dinamis merupakan salah satu arsip yang sangat penting keberadaannya. Menyadari pentingnya arsip tersebut sebagai memorial dan sumber informasi maka dengan tegas diatur dalam Undang-Undang Republik Indonesia Nomor 43 Tahun 2009 tentang kearsipan, yang menjamin keselamatan bahan pertanggungjawaban nasional tentang perencanaan, pelaksanaan, dan penyelenggaraan kehidupan kebangsaan yang harus selalu dijaga.

Arsip dinamis tidak dapat dipisahkan dari kegiatan operasional suatu lembaga. Hal ini disebabkan karena lembaga tentunya menjalankan kegiatan operasional, dalam menjalankan kegiatan operasional maka lembaga tersebut harus mempunyai bukti autentik yang sah. Bukti autentik tersebut adalah melalui arsip, yaitu arsip dinamis. (Mutiawatul, 2018)

Menurut penggunaannya berdasarkan UU Nomor 1 Tahun 1971, arsip dinamis dibedakan menjadi 2 yaitu dokumen aktif dan inaktif (Helmalia; 3) Arsip dinamis aktif adalah arsip yang frekuensi penggunaannya tinggi dan/atau 
secara terus menerus. Arsip Inaktif adalah arsip yang frekuensi penggunaannya telah menurun. (PERGUB No. 32 Tahun 2017)

2. Kegunaan Arsip Dinamis

Arsip sebagai dokumen yang dimiliki oleh setiap organisasi atau kantorsksn didimpsn dalam suatu tempat teratur sehingga setiap saat diperlukan dapat ditemukan dengan cepat. Alasan perlunya arsip disimpan karena mempunyai suatu nilai kegunaan tertentu (Nur Aini Astuti). Nilai guna arsip adalah nilai arsip yang didasarkan pada kegunannya bagi organisasi (Badri Munir Sukoco; 86). Ditinjau dari kepentingan organisasi, nilai guna arsip dibagi menjadi dua, yaitu:

1. Kegunaan bagi instansi pencipta arsip. Bagi instansi pencipta, kegunaan arsip antara lain meliputi: endapan informasi pelaksanaan kegiatan, pendukung kesiapan informasi bagi pembuat keputusan, sarana peningkatan efisiensi operasional instansi, memenuhi ketentuan hukum yang berlaku, dan sebagai bukti eksistensi instansi.

2. Kegunaan bagi kehidupan kebangsaan. Bagi kehidupan kebangsaan prestasi intelektual bangsa dan kegunaan arsip antara lain sebagai bukti pertanggungjawaban, memori kolektif, dan bukti sejarah. (Tari Lestsri)

Arsip dinamis dipergunakan dalam lingkup kegiatan dan disimpan sebagai bukti kebijakan dalam aktivitasnya yang masih dipergunakan secara langsung dalam kegiatan perkantoran sehari-hari. Dengan demikian, arsip dinamis memiliki ciri-ciri sebagai berikut: 
a. Arsip yang masih aktual dan berlaku secara langsung diperlukan dan dipergunakan dalam penyelenggaraan administrasi sehari-hari.

b. Arsip yang senantiasa masih berubah nilai dan artinya menurut fungsinya.

c. Pada dasarnya arsip dinamis bersitat tertutup, oleh karena itu pengelolaan dan perlakuannya harus mengikuti ketentuan tentang kerahasiaan surat-surat (Joner Hasugian)

3. Pengelolaan Arsip Dinamis di Dinas Kearsipan Provinsi Sumatera Selatan

Pengelolaan arsip dinamis meliputi penciptaan, penggunaan, pemeliharaan dan penyusutan arsip. Seperti yang dijelaskan dalam Undang-Undang Nomor 43 Tahun 2009 bahwa pengelolaan arsip dinamis adalah proses pengendalian arsip dinamis secara efisien, efektif, dan sistematis meliputi penciptaan, penggunaan dan pemeliharaan, serta penyusunan arsip. Pengelolaan arsip dinamis dilakukan untuk menjamin ketersediaan arsip dalam rangka penyelenggaraan kegiatan yang nantinya akan digunakan sebagai bahan akuntabilitas kinerja dan alat bukti yang sah bagi sebuah lembaga (Mutiawatul; 2018). Berikut tahapan pengelolaan arsip dinamis di Dinas Kearsipan Provinsi Sumsel:

a. Penciptaan arsip dinamis

Proses penciptaan arsip merupakan awal dari lahirnya suatu arsip dinamis aktif. Sebuah arsip yang akan diciptakan tentunya berdasarkan dengan analisis fungsi dan tugas organisasi yang bersangkutan. Penciptaan arsip juga harus memenuhi komponen 
struktur, isi dan konteks arsip. Untuk mendukung pengelolaan arsip dinamis yang efektif dan efisien pencipta arsip membuat tata naskah dinas, klasifikasi arsip jadwal retensi arsip dan akses arsip. Berbicara mengenai penciptaan arsip berikut contoh arsip dinamis aktif di Dinas Kearsipan Provinsi Sumatera Selatan:

Gambar 1.

Surat Masuk

Perihal Tertib Penyusunan RKBU fan RKA

b. Penggunaan arsip dinamiis

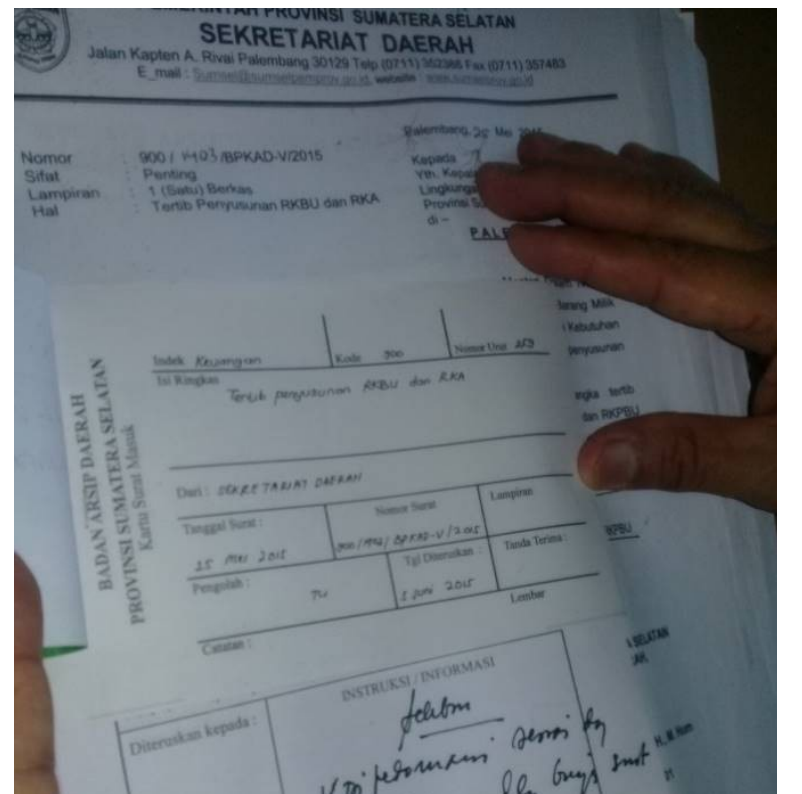

Penggunaan disini maksud́nía adalah penggunaan aktif dari suatu arsip dinamis oleh pemakai dengan jangka waktu beberapa hari bahkan bisa sampai tahunan, namun pada umumnya arsip dinamis memiliki siklus aktif sekitar satu sampai dua tahun, namun ada juga arsip dinamis yang memiliki siklus aktif lebih panjang. Di Dinas Kearsipan arsip yang memiliki jangka waktu penggunaan aktif harian adalah surat izin observasi dan SK pegawai 
merupakan arsip yang memiliki jangka penggunaan aktif selama pegawai masih bekerja di Dinas Kearsipan.

c. Pemeliharaan arsip dinamis

Pemeliharaan arsip dinamis adalah sebuah kegiatan mengenai penataan dan penyimpanan terhadap arsip dinamis aktif maupun inaktif. Penataan dan penyimpanan arsip bertujuan untuk temu kembali arsip dengan cepat dan tepat (Mutiawatul; 2018). Dalam hal penataan kode klasifikasi menjadi sarana penataan arsip yang disusun berdasarkan klasifikasi masalah bidang tugas unit kerja. Kode klasifikasi arsip terdiri atas:
a. umum
b. pemerintahan
c. politik
d. keamanan dan ketertiban
e. kesejahteraan rakyat
f. perekonomian
g. pekerjaan umum dan ketenagakerjaan
h. pengawasan
i. kepegawaian
j. keuangan

Dinas Kearsipan Provinsi Sumatera Selatan sudah menggunakan klasifikasi sejak tahun 1998. Ini artinya pengklasifikasian arsip sudah lama digunakan. Untuk

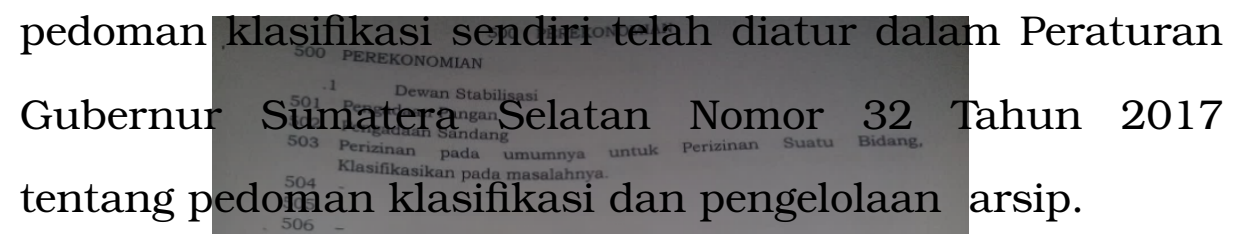

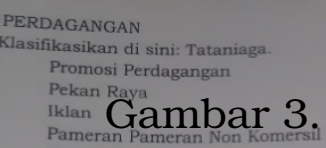

Kode Klasifikâsi Kelas 500 (Perekonomian) 
Adapun dalam kegiatan penyimpanan, arsip dinamis aktif disimpan di ruang sentral file dan arsip dinamis inaktif disimpan di tiga ruangan, yakni ruang rekod center 1 , rekod center 2 dan rekod center 3 dengan suhu ruangan $20^{\circ}$. Peralatan yang digunakan dalam penyimpanan arsip dinamis ada 3 jenis, yakni lemari besi, rak, dan box. Arsip yang dikelompokkan berdasarkan jenis dan tahunnya, kemudian dimasukkan kedalam box yang sudah dilengkapi dengan kode klasifikasi, jenis serta tahun. Box yang sudah berisi arsip disimpan ke dalam lemari besi, apabila lemari besi tidak dapat menampung semua box, sisanya akan diletakkan di rak dan apabila rak juga tidak dapat menampung maka box arsip

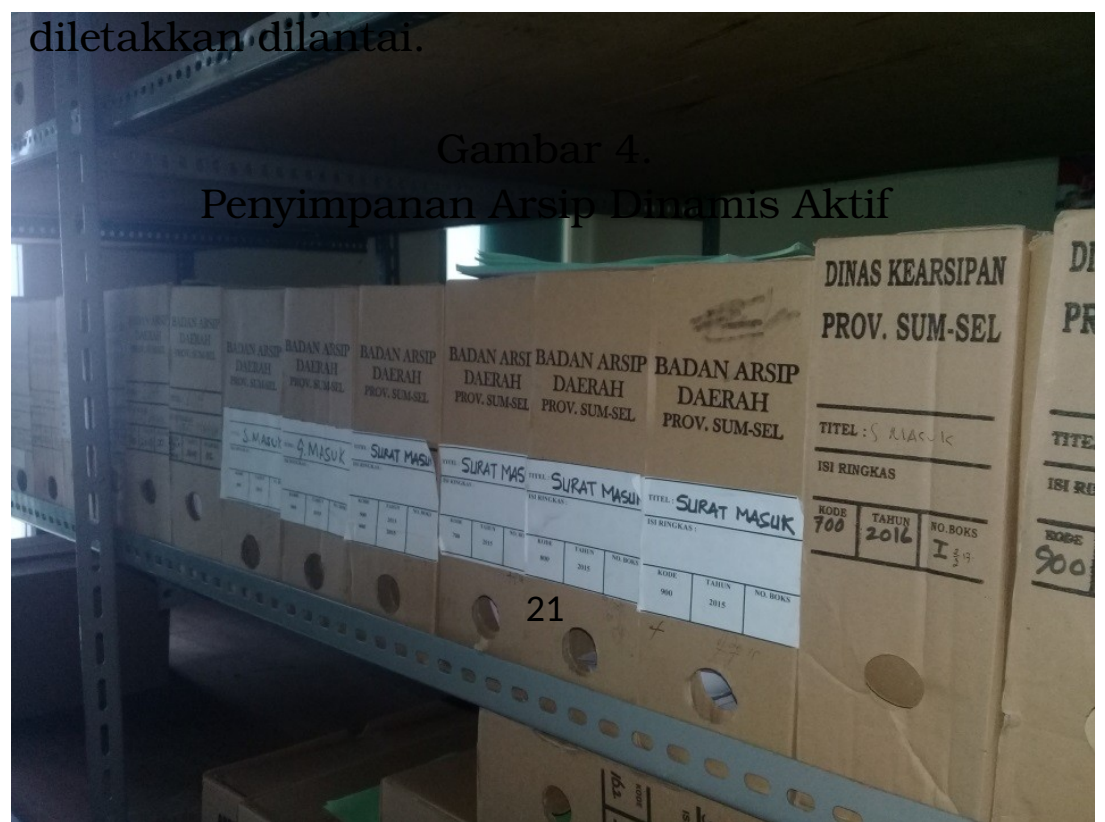


Gambar 5.

Penyimpanan Arsip Dinamis Inaktif di Lemari Besi

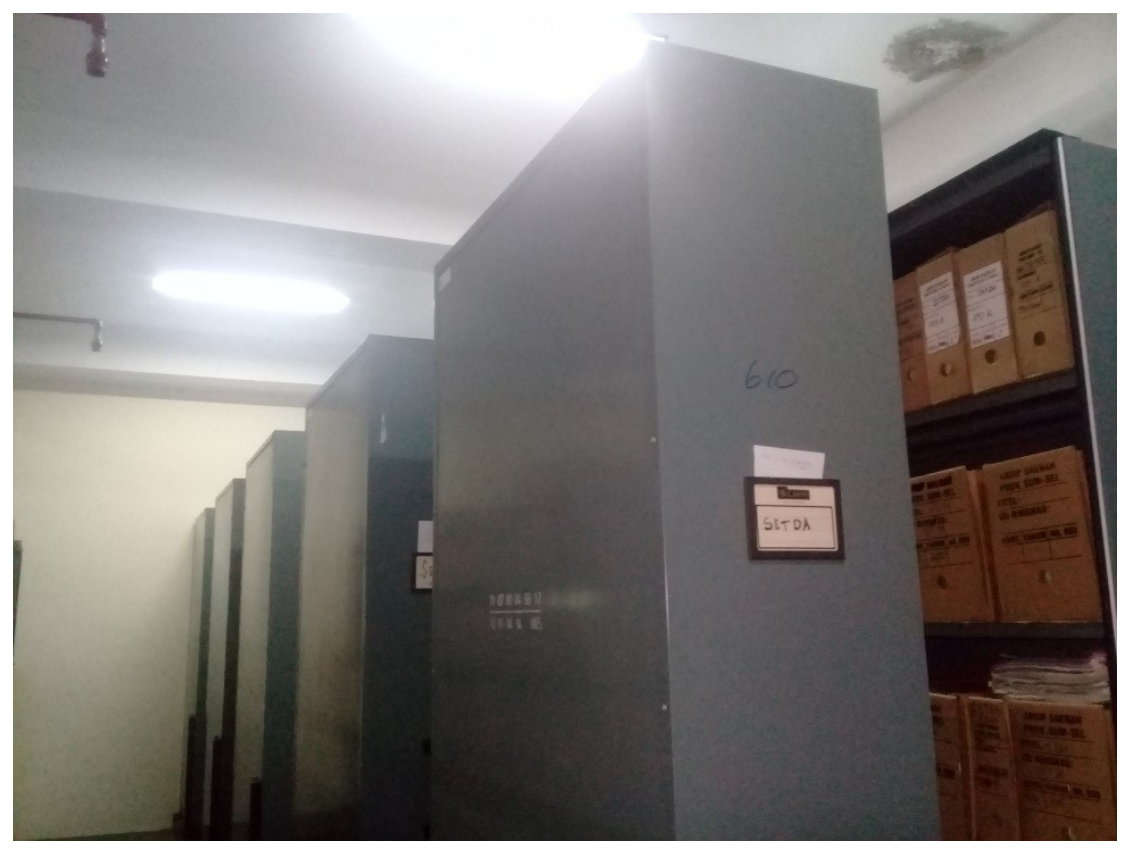

Gambar 6.

Penyimpanan Arsip Dinamis Inaktif di Rak 


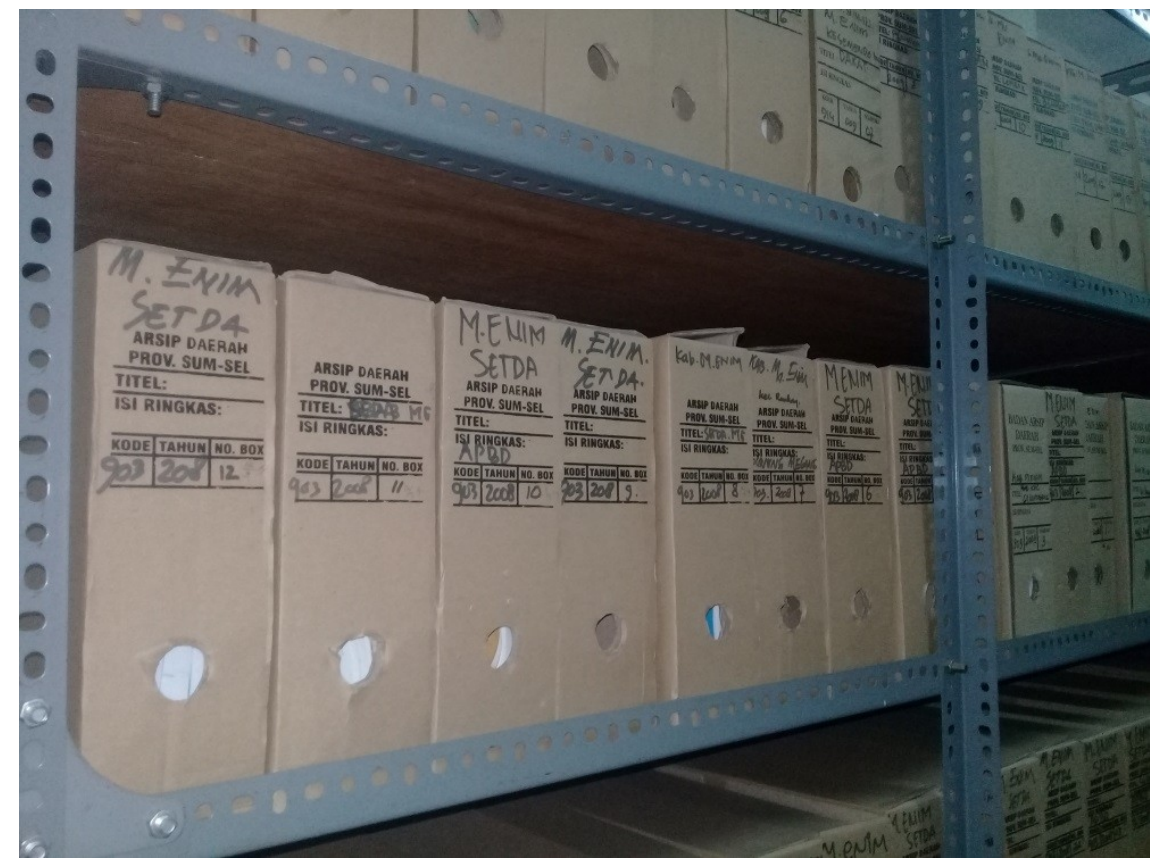

d. Penyusustan arsip dinamis

Penyusutan adalah suatu tindakan yang diambil berkenaan dengan habisnya "masa simpan" arsip yang telah ditentukan oleh perundang-undangan, peraturan atau prosedur administratif. Tindakan ini harus dilakukan untuk mengatasi menumpuknya arsip, sehingga sulit ditemukan kembali (retrieval) dan sulit memeliharanya, sebab karakteristik arsip ialah mengumpul secara alami (accumulating naturally). Dengan demikian penyusutan arsip diperlukan untuk menghemat ruangan/tempat, memudahkan penemuan kembali arsip jika diperlu-kan. Pada dasarnya penyusutan arsip didasarkan pada JRA (Jadwal Retensi Arsip).

Langkah-langkah penyusutan arsip sebelum dilakukannya pemusanahan di Dinas Kearsipan Provinsi Sumsel :

1. Bagian tata usaha pengolah 
a. secara teratur mengadakan penelitian untuk menentukan arsip inaktif.

b. memisah-misahkan arsip yang dapat dimusnahkan dan yang akan dikirim ke penyimpanan.

c. menata arsip inaktif yang akan diserahkan ke penyimpanan dalam file tersendiri.

d. pada waktu yang telah ditentukan, mengirim arsip inaktif tersebut ke penyimpanan.

2. Bagian unit kearsipan, secara teratur melakukan penelitian arsip yang sudah melampaui jadwal retensi.

Tata cara pemusnahan arsip di Dinas Kearsipan Provinsi Sumsel:

1. Penyimpanan sekali dalam setahun berkewajiban:

a. meneliti dan memisahkan arsip yang telah melebihi jangka waktu dalam yang telah ditentukan dalam jadwal retensi .

b. membuat daftar arsip yang berdasarkan jadwal retensi arsip dapat dimusnahkan.

c. mengumpulkan arsip tersebut dan diajukan ke tim penilai.

d. memberitahukan kepada unit pengolah dengan daftar arsip, bahwa arsip telah memenuhi jangka telah ditentukan dalam jadwal retensi dan telah disetujui oleh tim penilai untuk dimusnahkan.

2. Proses pemusnahan arsip:

a. tim penilai/peniliti mengajukan permintaan persetujuan tentang pemusnahan arsip kepada Kepala Arsip Nasional Republik Indonesia. 
b. petugas yang melaksanakan pemusnahan membuat berita acara tentang pelaksanaan pemusnahan arsip.

c. melakukan pemusnahan arsip apabila telah disetujui oleh pihak ANRI.

Metode pemusnahan arsip yang digunakan pihak Dinas Kearsipan adalah pencacahan, metode ini memang lazim digunakan di Indonesia untuk memusnahkan dokumen dalam bentuk kertas dengan menggunakan alat pencacah. Adapun jangka waktu pemusnahan arsip adalah 10 tahun.

Gambar 7.

Alat Pencacahan Kertas

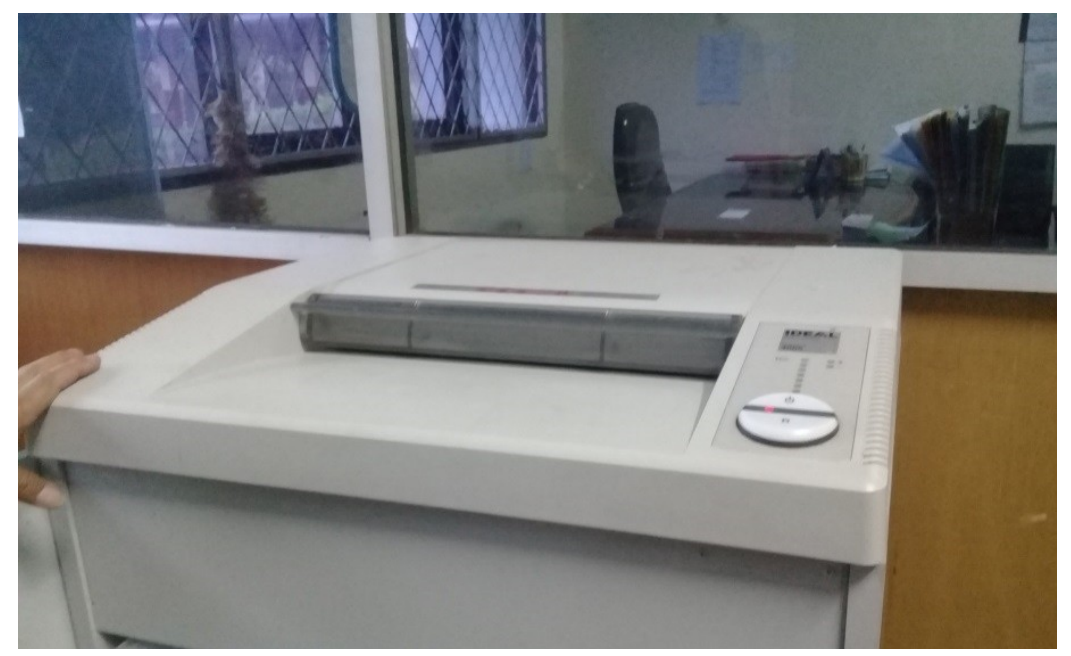

Gambar 8.

Hasil dari pencacahan kertas

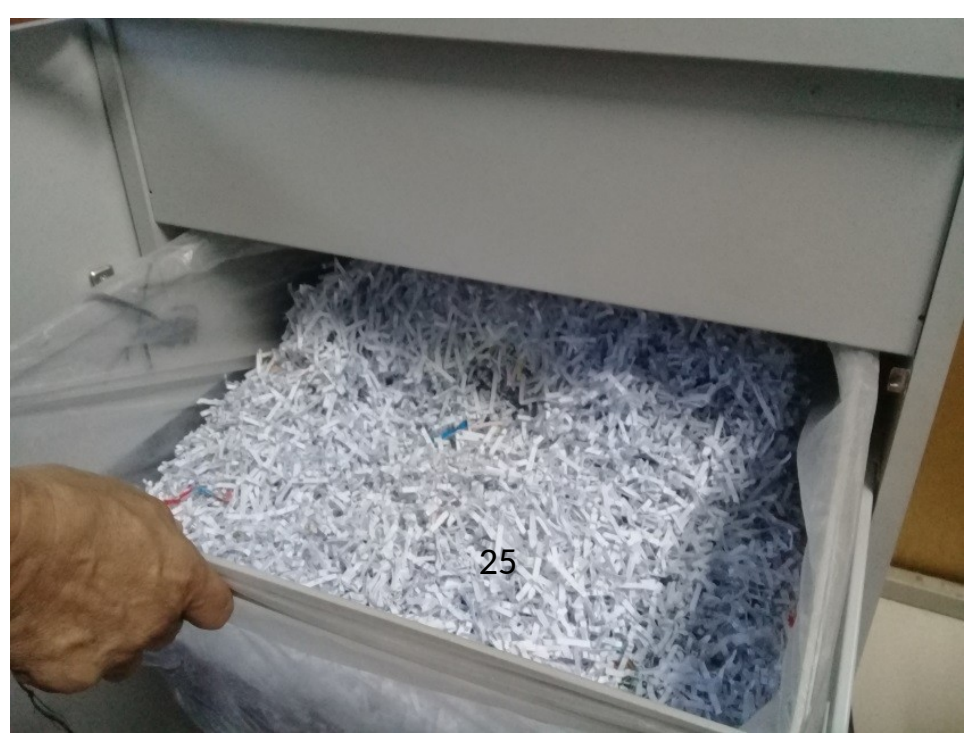


4. Sistem Temu Kembali Arsip di Dinas Kearsipan Provinsi Sumatera Selatan

Temu kembali arsip atau dokumen adalah cara bagaimana suatu dokumen atau arsip dapat dengan mudah ditemukan dalam waktu yang cepat dan tepat. Sistem temu kembali arsip atau dokumen tentunya sangat berhubungan dengan sistem penataan dan penyimpanan dokumen atau arsip. Karena jika penataan dan penyimpannan arsip dekelola dengan baik maka temu kembali arsip lebih mudah. Adapun sistem temu kembali arsip di Dinas Kearsipan masih menggunakan sistem manual, yakni pencipta arsip mengisi formulir tanda bukti pinjaman. Barulah arsiparis akan mencarikan arsip yang diinginkan oleh pencipta.

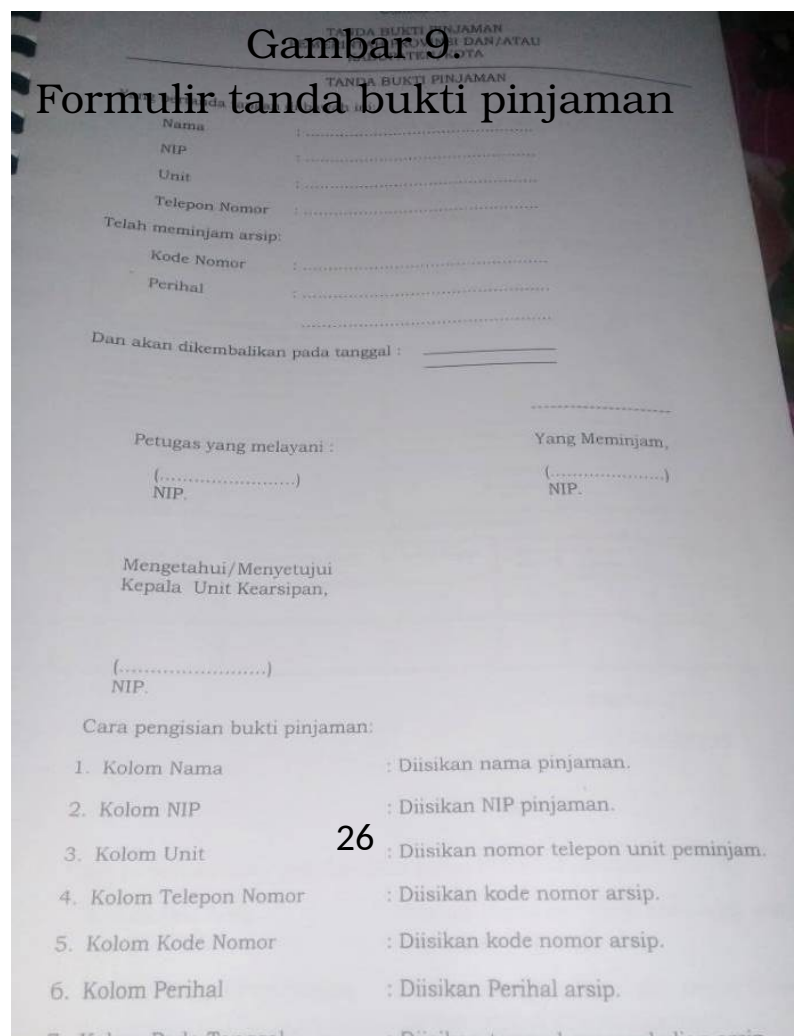


5. Kendala-Kendala dalam Pengelolaan Arsip Dinamis di Dinas Kearsipan Provinsi Sumatera Selatan

Adapun kendala-kendala dalam pengelolaan arsip dinamis yang dihadapi, yaitu:

1. Fasilitas

a. Kurangnya peralatan penyimpanan seperti lemari besi dan rak, sehingga menyebabkan arsip yang sudah di simpan dalam box menumpuk dan hanya disusun biasa diatas lantai tanpa alas.

b. Terbatasnya fasilitas kearsipan yang ada menyebabkan pengelolaan arsip dinamis aktif kurang berjalan optimal.

2. Sumber Daya Manusia

Kurangnya jumlah Arsiparis berakibat pada pengelolaan arsip dinamis kurang maksimal, apalagi dengan jumlah arsip yang banyak dan semakin hari akan terus bertambah.

Berdasarkan paparan yang telah dikemukakan di atas, maka dapat disimpulkan bahwa kendala yang dihadapi dalam 
pengelolaan arsip dinamis yaitu dari segi fasilitas, baik itu sarana maupun prasarana dan dari segi sumber daya manusia kearsipan. Tentunya dengan kendala dari segi fasilitas sangat berpengaruh dalam hasil yang akan disajikan terhadap pengelolaan arsip dinamis yang dapat menyebabkan pengelolaan arsip dinamis tidak optimal.

\section{Penutup}

Kesimpulan dari penelitian ini adalah:

Pengelolaan arsip dinamis di Dinas Kearsipan Provinsi Sumatera Selatan dalam hal penciptaan menjadi tanggung jawab pencipta arsip, yakni pencipta arsip membuat tata naskah dinas, klasifikasi arsip, jadwal retensi arsip dan akses arsip untuk mendukung pengelolaan arsip dinamis yang efektif dan efisien. Penataan arsip dilakukan dengan menggunakan kode klasifikasi, yakni disusun berdasarkan klasifikasi masalah bidang tugas unit kerja. Dinas Kearsipan Provinsi Sumatera Selatan sudah menggunakan klasifikasi sejak tahun 1998. Untuk pedoman klasifikasi sendiri telah diatur dalam Peraturan Gubernur Sumatera Selatan Nomor 32 Tahun 2017 tentang pedoman klasifikasi dan pengelolaan arsip.

Penyimpanan arsip, arsip dinamis aktif disimpan di ruang sentral file dan arsip dinamis inaktif disimpan di tiga ruangan, yakni ruang rekod center 1 , rekod center 2 dan rekod center 3 dengan suhu ruangan $20^{\circ}$. Peralatan yang digunakan dalam penyimpanan arsip dinamis ada 3 jenis, yakni lemari besi, rak, dan box. Arsip yang dikelompokkan berdasarkan jenis dan tahunnya, kemudian dimasukkan kedalam box yang sudah dilengkapi dengan kode klasifikasi, jenis serta tahun. 
Penyusutan arsip juga merupakan salah satu komponen dalam pengelolaan arsip dinamis. Penyusutan arsip dilakukan untuk mengatasi menumpuknya arsip, sehingga sulit ditemukan kembali dan sulit memeliharanya. Penyusutan arsip dapat dilakukan dengan cara pemusnahan arsip, akan tetapi sebelum dilakukannya pemusnahan arsip ada beberapa hal yang perlu dilakukan, yakni melakukan penilaian terhadap arsip apakah arsip tersebut akan dimusnhakan atau di pindahkan ke arsip statis dengan membuat JRA (Jadwal Retensi Arsip). Setelah dilakukan penilaian, peniliti mengajukan permintaan persetujuan tentang pemusnahan arsip kepada Kepala Arsip Nasional Republik Indonesia, lalu membuat berita acara tentang pelaksanaan pemusnahan arsip dan barulah pemusnahan arsip bisa dilakukan apabila telah disetujui oleh pihak ANRI. Metode pemusnahan arsip di Dinas Kearsipan Provinsi Sumsel menggunakan metode pencacahan, selanjutnya hasil dari pencacahan akan dikirim ke pabrik kertas.

Adapun sistem temu kembali arsip di Dinas Kearsipan masih menggunakan sistem manual, yakni pencipta arsip mengisi formulir tanda bukti pinjaman. Barulah arsiparis akan mencarikan arsip yang diinginkan oleh pencipta. Sistem layanan di Dinas Kearsipan adalah layanan tertutup sehingga pencipta arsip tidak dapat langsung ke ruangan arsip.

\section{Daftar Pustaka}

3 Instrumen Pengelolaan Arsip Dinamis, dalam http://mpi.muhammadiyah.or.id/download-materipelatihan-arsip-ptm-1026.html 
Anon Mirmani. Pengantar Kearsipan. Jakarta: Universitas Terbuka, 2011. hal 1.11

Badri Munir Sukoco. Manajemen administrasi perkantoran Modern. Jakarta: Erlangga, hal 86, dalam https://books.google.co.id/books?id=F_5Th5XQfAC\&printsec $=$ frontcover\&hl $=\mathrm{id} \# \mathrm{v}=$ onepage \&q $\& \mathrm{f}=$ false

Cusing, Amber L. Highlighting the Archives Perspective in the Personal Digital Archiving Discussion, EMERALD: Library Hi Tech, Vol. 28 Iss 2 (2010), 302, dalam https://www.emeraldinsight.com/doi/full/10.1108/073788 31011047695

Helmalia. Peningkatan Mutu Kinerja Karyawan Melalui Manajemen Arsip dalam Meningkatkan Kualitas Pelayanan Publik di KJKS BMT. dalam https://journal.febi.uinib.ac.id/index.php/jebi/article/view/ 120

Jonner Hasugian. "Pengantar Kearsipan”, Universitas Sumatera Utara, dalam http://repository.usu.ac.id

Mutiawatul. Pengelolaan Arsip Dinamis, dalam http://moraref.kemenag.go.id/documents/article/97406410 $\underline{605922368}$.

Nur Aini Astuti. Pengelolaan arsip dinamis aktif pada sub bagian umum dinas pertanian dan kehutanan kabupaten bantul Yogyakarta, dalam http:/ / eprints.uny.ac.id/28392/1/SKRIPSI\%20NUR\%20AINI \%20ASTUTI-NIM.\%20094022441039\%20.pdf

PERGUB No. 32 Tahun 2017 tentang Pedoman Klasifikasi dan Pengelolaan arsip, dalam http://jdih.sumselprov.go.id/index.php? module $=$ page $\& i d=$ perda\&idx $=$ perda $\&$ tahun $=2017 \& i d v=$ Perat uran\%20Gubernur\%20Sumatera\%20Selatan\&hal=2

Tari Lestari. Kegunaan Arsip, dalam https://www.scribd.com/document/349467389/KEGUNAA N-ARSIP

Wakimoto. Experiencing Archives at Universities: Archivists, librarians, understanding, and collaboration, EMERALD: Vol. 43 No. 2 (2015), 188, dalam https://www.emeraldinsight.com/doi/full/10.1108/RSR-072014-0025

Zulkifli Amsyah. Manajemen Kearsipan. Jakarta: Gramedia Pustaka Utama, 2003. hal 2 